\title{
Social networks and social ties: Changing trends of polit- ical participation among youth in Punjab-Pakistan
}

\author{
Muhammad Saud * \\ Faculty of Social and Political Science, Universitas Airlangga, Surabaya, Indonesia
}

\author{
Keywords \\ Social networks \\ Youth \\ Political participation \\ Political parties \\ Bhakkar \\ Pakistan
}

Received: 16 August 2018

Accepted: 18 September 2018

Published: 31 October 2018

\begin{abstract}
The aim of the study was to explore the importance of social networks in political participation among youth in Punjab Pakistan. The premise was to find out the association between social networks and youth political participation. For this purpose, quantitative research design was deployed and survey was conducted on 308 respondents including male and female having age ranges from 18-29 years. Keeping in view the objectives of research, a structured questionnaire was used as research instrument while univariate analysis has been done. Province of Punjab was selected as universe of the study on the basis of having strong ties among each other. The findings revealed that most of the respondents had casted their votes and had strong ties among their associations including relatives, friends and community. The results further found that youth was an active participant in different political activities such as involvement in community matters, organizing seminars on social issues, participation in campaign raising walks, participation in civic engagement and association with formal or informal organization. The study also provided the findings regarding relationship of respondents' social network support with political participation with the correlation value $.261^{* *}$. The present study also provides few recommendations.
\end{abstract}

(C) 2018 The Author(s). Published by TAF Publishing.

\section{INTRODUCTION}

The most recent leadership transition of Pakistan took place in 2003 from dictatorship to democracy. A new trend in the Pakistani politics is that an increasing number of young people are promoted, which is especially obvious in the May 2013, general elections. The positive relationship between education and political participation is one of the most reliable results in empirical social science. Better educated citizens are more likely to be engaged by the political process, and they are more likely to become involved in various political activities. In the political history of Pakistani the country has dominated by few small families and dictators. Common man has suffered at the hands of aristocrats and among those common men lives the young men and women, who are spoken highly. The history tells us that political parties have always used the youth to achieve their political targets but looking at the bigger picture, the role of youth in Pakistani politics has always been limited. Social ties are not factions, but are important building blocks of Party's political networks. This paper will examine the factors of the social network behind the youth how they are participating in politics. Social networks have key role in promoting and increasing politics in Pakistan. Social network is a social structure made up of a set of social actor and a set of dyadic ties between the actors. The social network perspective provides a set of methods for analyzing the structure of whole social entities as well as a variety of theories explaining the patterns observed in these structures. Social network is to study relationships between individuals, groups or even entire societies. The term is used to describe a social structure determined by such interactions. The ties through which any given social unit connects represent the convergence of the various social contacts of that unit. Social networks are the mechanism that connects micro and macro levels of social life in the community (Coleman, 1991; Mansouri \& Mhunpiew, 2016; Nuchso, Tuntivivat, \& Klayklueng, 2016). Political participation extends beyond parties, however youth can also become in-

* corresponding author: Muhammad Saud

†email: muhhammad.saud@gmail.com 
volved in certain aspects of the electoral process through independent action particularly at the local level and by joining civil society organizations, professional networks, trade unions, non-governmental organizations, and the social networks can all provide avenues for youth political participation. In the light of the attention in the Pakistani press with regard to the youth participation in the 2013 Pakistani elections (Zaidi, 2013; Solihah, Djuyandi, \& Rahmatunnisa, 2018), young Pakistanis are increasingly participating in mainstream politics and their views to mobilize young or old people to vote for a certain political agents. Ryan, Agnitsch, Zhao, and Mullick (2005) illustrated the relationship between social ties and community participation is complementary in nature. The more connected people are to their community the more likely it is that they will participate in voluntary activities. European Union Election Observation Mission (2013) prepared report on general elections 2013 in Pakistan. According to report the electoral process progressed with high level of voter turnout.

\section{METHODS}

The universe of this study was limited to Punjab province of Pakistan. Researcher has adopted quantitative research design to find out the role of social networks in creating the political participation among youth. Sample size of 308 respondents was drawn through target population. Researcher used proportionate random sampling technique for data collection. The unit of analysis of the present research was youth of the targeted area and under the age of 18-29 Years. Statistical Package for Social Sciences (SPSS) was used to analyze and compile the data. Simple frequency tables were made to interpret the data and percentage of different categories were obtained by using formula. In the present study correlation statistics was applied to see the relationship between various independent and dependent variables. Putnam (2001) found that social relationships between membership in social organizations and political involvement include arguments that the membership stimulates a collective interest in political activities. Stern and Adams (2010) stated that two main types of youth participation which contribute to a community are nominal and active. Nominal includes membership in a voluntary organization or attending a local event. Active participation refers to "taking a role in or making an investment in the success of the group participating in actions aimed at community change through social relationship". Ryan et al. (2005), Stern and Adams (2010) explained that different types of ties and relationships could affect crucial facets of social network, such as levels of youth participation in politics.
More the people connected to their community, more likely it is that they will participate in voluntary activities. Allen (2018) argued that youth age group has higher levels of local involvement than other members of the community, because young people are very much interested in the community building works. Norris (2002) illustrated that indirect participation could also have benefits for the young volunteers as it can open doors to social networks that may have been previously untapped or underdeveloped.

\section{RESULT AND DISCUSSION}

TABLE 1. Respondents regarding their age

\begin{tabular}{lll}
\hline \hline Age (years) & Frequency & Percent \\
\hline $18-21$ & 143 & 47.8 \\
$22-25$ & 101 & 30.7 \\
$26-29$ & 64 & 21.5 \\
Total & 308 & 100.0 \\
\hline \hline
\end{tabular}

Table 1 states the age group of the respondents. Less than half $(47.8 \%)$ were in the age group of $18-21$ years, $30.7 \%$ of the respondents were in the age group of 22-25 years; however, $21.5 \%$ of the respondents were in 26-29 years of age. Putnam (2001) defined social networks as a social fabric that creates willingness to cooperate in the development of physical capital, as an explanatory variable in the generation of human capital between generations and as an aspect of social structure that facilitates particular forms of action and cooperation. This table shows that less half of the respondents belonged to 18-21 years of age.

TABLE 2. Respondents regarding their gender

\begin{tabular}{lll}
\hline \hline Gender & Frequency & Percent \\
\hline Male & 175 & 57.0 \\
Female & 133 & 43.0 \\
Total & 308 & 100.0 \\
\hline \hline
\end{tabular}

Table 2 represents the gender of the respondents. A little more than half of the respondents (56\%) were males while $43 \%$ were females. Hence, it can be deduced from above table that most of the respondents were male because they are frequently participating in civic engagement activities while the females are less active. In other words, youth are committed to the tenets of democracy, but tend to be more interested in participative political behaviour and issues which are immediately pertinent to their lives. It is came to attention that males have more tendencies toward political participation than females. 
TABLE 3. Respondents regarding their area of residence

\begin{tabular}{lll}
\hline \hline Area & Frequency & Percent \\
\hline Urban & 169 & 54.9 \\
Rural & 139 & 45.1 \\
Total & 308 & 100.0 \\
\hline \hline
\end{tabular}

Table 3 reflects area of residence of the respondent's. More than half of the respondents $(54.9 \%)$ were from urban dwellings, and remaining $45.1 \%$ belonged to rural settlements. Wellman and Frank (2001) clarified that the networks of social ties that arise from and contribute to the community participation are also an essential component of networking and may enhance the youth participation to the mobilization in community building. Due to increasing urbanization respondents from small towns and urban sprawling considered themselves as urban citizens so more than half of the respondents (54.9\%) mentioned urban background.

TABLE 4. Respondents regarding casted their vote in elections

\begin{tabular}{lll}
\hline \hline Vote & Frequency & Percent \\
\hline Casted & 217 & 70.5 \\
Not casted & 91 & 29.5 \\
Total & 308 & 100.0 \\
\hline
\end{tabular}

Table 4 expounds the respondent's casted vote in the general elections. Majority (70.5\%) of the respondents casted their vote in the elections and $29.5 \%$ did not cast their votes. The mentioned table clearly shows that majority (70.5\%) of the respondents casted their votes in the general elections. It further shows that respondents are formally showing their political behaviour.

TABLE 5. Respondents by motivated their friends and colleagues

\begin{tabular}{lll}
\hline \hline Motivate & Frequency & Percent \\
\hline Never & 75 & 24.4 \\
Rarely & 24 & 7.7 \\
Sometime & 71 & 23.1 \\
Very often & 57 & 18.5 \\
Always & 81 & 26.3 \\
Total & 308 & 100.0 \\
\hline \hline
\end{tabular}

Table 5 Putnam (2001) illustrated that the social interaction in the community such as political events, attending community meetings, or being political agent may make people more likely to participate by increasing interpersonal trust and adherence to social unity. This table defines the descriptive results of dependent variables i.e., frequency of having civic participation and motivate friends and colleagues to participate in events for awareness on social issues. The findings indicate that $24.4 \%$ of the respondents never motivated their friends for awareness on social issues whereas $7.7 \%$ of the respondents rarely participated.

One fourth $26.3 \%$ of the respondents have always motivated their friends for participation in the social cause events. The last category showed that $23.1 \%$ of the respondents sometime involve in the awareness events. Ryan et al. (2005), Stern and Adams (2010) explained the different types of ties and relationships can affect crucial facets of social network, such as levels of youth participation in politics.

Sproull, Conley, and Moon (2005) said the social networks provide a medium through which community members can obtain information on local events and meetings from each other and it create harmony between the different sects and class of the community. The findings in the table clearly show that one fourth of the respondents i.e., $26.3 \%$ participated in the the events of the social issue and motivated their friends for civic participation.

TABLE 6. Respondents by motivated their friends and colleagues to participate in events

\begin{tabular}{lll}
\hline \hline Participation & Frequency & Percent \\
\hline Never & 63 & 20.5 \\
Rarely & 32 & 10.4 \\
Sometime & 68 & 22.1 \\
Very often & 58 & 18.8 \\
Always & 87 & 28.2 \\
Total & 308 & 100.0 \\
\hline \hline
\end{tabular}

Table 6 Huckfeldt (2001) revealed the fact that the importance of social interaction will enhance the interpersonal social networks in the community which is leading to the electoral activities and civic engagement. This table shows the descriptive results of dependent variables i.e., frequency of having civic participation being participated in the local community problem solving. The findings illustrated that $20.5 \%$ of the respondents never participated in the community problem solving segments whereas $10.4 \%$ of the respondents rarely participated. One fourth $28.2 \%$ of the respondents were always attended the local community meetings for solutions.

Fukuyama (1995) described the social capital has been addressed as trust in social relations as civic engagement created through participation in voluntary associations in the 
community by the formal and informal social relationships. The last category showed that $22.1 \%$ of the respondents sometime involved in the community meetings.

Putnam (2001) predicted that social capital matters, Putnam and others argue, social capital brings people together to solve common problems. The findings in the table clearly show that one fourth of the respondents i.e., $28.2 \%$ participated in the social issues community meetings which indicate their role of civic participation in the community. Thus, civic engagement involves working to make a difference in the civic life of 'we feelings' in community and developing the combination of knowledge, skills and motivation to make that difference.

TABLE 7. Respondents by sharing their political views with others

\begin{tabular}{lll}
\hline \hline Political Views & Frequency & Percent \\
\hline Never & 78 & 25.3 \\
Rarely & 12 & 3.9 \\
Sometime & 58 & 18.8 \\
Very often & 59 & 19.2 \\
Always & 101 & 32.8 \\
Total & 308 & 100.0 \\
\hline \hline
\end{tabular}

Table 7 states the descriptive results of dependent variables i.e., frequency of having political participation sharing their political views among others. The findings illustrated that $25.3 \%$ of the respondents were those who never shared their political views among others whereas $18.8 \%$ of the respondents have among those who sometime shared their political views. One third $32.8 \%$ of the respondents were always shared their political views with their social networks. The last category showed that $19.2 \%$ of the respondents were those who very often shared their views.

TABLE 8. Distribution of the respondents to caste vote in favor of a particular party

\begin{tabular}{lll}
\hline \hline Vote & Frequency & Percent \\
\hline Never & 131 & 42.5 \\
Rarely & 9 & 2.9 \\
Sometime & 43 & 14.1 \\
Very often & 38 & 12.3 \\
Always & 87 & 28.2 \\
Total & 308 & 100.0 \\
\hline \hline
\end{tabular}

Table 8 Political affiliation means inclination towards any political party, the support for political party and the po- litical party's ideology you support, this table depicts the descriptive results of dependent variables i.e., frequency of having political participation to motivate others to vote for a specific party or candidate. The findings illustrated that $42.5 \%$ of the respondents never persuaded anyone for any candidate or party whereas $14.1 \%$ of the respondents sometime tried to motivate others. The last category showed that $28.2 \%$ of the respondents always tried to persuade other to vote for a candidate or party.

The findings in the table clearly show that less than half of the respondents i.e., $42.5 \%$ were never persuaded to vote for any specific party or candidate.

TABLE 9. Respondents by collected information about political parties

\begin{tabular}{lll}
\hline \hline Info & Frequency & Percent \\
\hline Never & 145 & 47.1 \\
Rarely & 24 & 7.8 \\
Sometime & 26 & 8.4 \\
Very often & 52 & 16.9 \\
Always & 61 & 19.8 \\
Total & 308 & 100.0 \\
\hline \hline
\end{tabular}

Political talk as a social practice that is embedded in everyday times and public spaces. Schmitt and Lup (2013) explained that political sharing has been defined as 'a specific type of social interaction' which shows itself in the form of discrete events where two or more people engage in exchanges of meaning with reference to politics. The findings in the table clearly show that one third of the respondents i.e., $32.8 \%$ always shared their political views with others which indicate their political interests in the community.

Table 9 explains the descriptive results of dependent variables i.e., frequency of having political participation being involved in gathering information for the candidates and political parties. The findings illustrated that $47.1 \%$ of the respondents were those who never gathered information about the others political parties or candidates whereas $16.9 \%$ of the respondents were among those who very often gathered information. The last category showed that 19.8\% of the respondents were those who were always gathered information about the political parties or candidates.

The findings in the table clearly shows that less than half of the respondents i.e., $47.1 \%$ never involved in gathering information about the political parties or candidates in the 2013 general elections which indicates their lack of interest in political participation. 
TABLE 10. Distribution of the respondents to motivated other people to caste vote for a particular party

\begin{tabular}{lll}
\hline \hline Motivate & Frequency & Percent \\
\hline Never & 93 & 30.2 \\
Rarely & 24 & 7.8 \\
Sometime & 42 & 13.6 \\
Very often & 41 & 13.3 \\
Always & 108 & 35.1 \\
Total & 308 & 100.0 \\
\hline \hline
\end{tabular}

Table 10 Allen (2018) defines that formal and informal social interaction can be lumped together under the rubric of social capital while group effects and social network effects imply that they should influence behavior in distinct ways. This table presents the descriptive results of dependent variables i.e., frequency of having political participation for motivating others to cast their vote for the particular party or candidate.

The findings illustrated that $30.2 \%$ of the respondents were those who never motivated other people to vote for a particular candidate or party whereas $13.6 \%$ of the respondents were among those who sometime involve in political campaigns. One third $35.1 \%$ of the respondents always motivated their social networks to vote for their party. The last category shows that $13.3 \%$ of the respondents were those who very often involved in the promotional campaigns. The findings in the table clearly show that one third of the respondents i.e., $35.1 \%$ were involved in motivating others to vote for a particular party.

TABLE 11. Respondents regarding dissemination of any literature or campaign materials

\begin{tabular}{lll}
\hline \hline Literature & Frequency & Percent \\
\hline Never & 179 & 58.1 \\
Rarely & 12 & 3.9 \\
Sometime & 32 & 10.4 \\
Very often & 46 & 14.9 \\
Always & 39 & 12.7 \\
Total & 308 & 100.0 \\
\hline \hline
\end{tabular}

Table 11 describes the descriptive results of dependent variables i.e., frequency of having political participation disseminated the literature or campaign material. The findings illustrated that 58.1\% respondents were those who never distributed any campaign literature whereas $10.4 \%$ respondents were among those who sometime distributed. The last category showed that $12.7 \%$ respondents were those who were always distributing the political party literature
TABLE 12. Percentage of the respondents regarding their close friends and shared private matters with them

\begin{tabular}{lll}
\hline \hline Close Peers & Frequency & Percent \\
\hline $0-2$ & 162 & 52.6 \\
$3-4$ & 74 & 24.0 \\
$5-8$ & 39 & 12.7 \\
$>=9$ & 33 & 10.7 \\
Total & 308 & 100.0 \\
\hline \hline
\end{tabular}

for campaign. The findings in the table are clearly showing that most of the respondents i.e., $58.1 \%$ were those who never disseminated any literature for political campaign in the general elections.

Table 13 describes the descriptive results of independent variables i.e., frequency of having social networks with relatives and how many between them you can talk your private matters. The findings showed that $52.6 \%$ respondents were those who interacted and share their private matters with their 0-2 friends whereas $24.0 \%$ respondents were among those who were in contact of their 3-4 friends for help and support. While $12.7 \%$ respondents were in contact of their 5-8 peer groups can share their private matters. The last category showed that $10.7 \%$ respondents were those who were in contact of their $>=9$ and above friends.

The outcomes in the table are clearly showing that most of the respondents i.e., $52.6 \%$ were in contact of their $0-2$ friends and can help or can talk about the private matters which are also an indication to the fact that in the study area people were having stronger peer social networks.

TABLE 13. Distribution of the respondents regarding elected as a party representative for national elections

\begin{tabular}{lll}
\hline \hline Representative & Frequency & Percent \\
\hline Never & 178 & 57.8 \\
Rarely & 10 & 3.3 \\
Sometime & 33 & 10.7 \\
Very often & 26 & 8.4 \\
Always & 61 & 19.8 \\
Total & 308 & 100.0 \\
\hline \hline
\end{tabular}

Table 13 depicts the descriptive results of dependent variables i.e., frequency of having political participation worked being as a party representative for national elections. The findings illustrated that $57.8 \%$ of the respondents were those who never worked as a party representative for elections whereas $10.7 \%$ of the respondents were among those who sometime worked for the party representative. The last category showed that $19.8 \%$ of the respondents always performed their duties for party. 
The findings in the table clearly show that more than half of the respondents i.e., $57.8 \%$ participated and worked as a party representative for the national elections.

TABLE 14. Donated money for supporting political candidate

\begin{tabular}{lll}
\hline \hline Donation & Frequency & Percent \\
\hline Never & 208 & 67.5 \\
Rarely & 12 & 3.9 \\
Sometime & 25 & 8.1 \\
Very often & 10 & 3.3 \\
Always & 53 & 17.2 \\
Total & 308 & 100.0 \\
\hline \hline
\end{tabular}

Table 15 expresses the descriptive results of dependent variables i.e., frequency of having political participation to donate money to the candidate or party. The findings illustrated that $3.9 \%$ of the respondents were those who rarely donated money to the candidates whereas $17.2 \%$ of the re- spondents were among those who always donated. The majority $67.5 \%$ of the respondents were always donated money for the party political campaigns. The last category showed that $8.1 \%$ respondents sometime donated the money to the candidates. The findings in the table clearly shows that majority of the respondents i.e., $67.5 \%$ never donated money or something to the political party or candidate in the 2013 general elections.

Table 15 To measure the political efficacy of the respondent five points likert scale was used encored from 5 strongly agree to 1 strongly disagree. The table demonstrates the opinion of the respondents about their knowledge of the political issues. One fourth of the respondents $29.9 \%$ agreed with easily understand the political issues, out of which $5.8 \%$ strongly disagreed and $29.5 \%$ agreed. About $16.6 \%$ disagreed and $5.8 \%$ in strongly disagree. The remaining one fourth $(18.2 \%)$ had neutral opinion in this regard.

TABLE 15. Frequency distribution of the respondent according to political efficacy

\begin{tabular}{|c|c|c|c|c|c|c|c|}
\hline Statements & SA & $\mathbf{A}$ & $N$ & $\mathbf{D}$ & $S . D$ & Mean & S.D \\
\hline \multirow{2}{*}{$\begin{array}{l}\text { When political issues or problems are being discussed, I usually have something } \\
\text { to say. }\end{array}$} & 92 & 91 & 56 & 51 & 18 & & \\
\hline & $(29.9)$ & $(29.5)$ & $(18.2)$ & $(16.6)$ & $(5.8)$ & 2.48 & 1.401 \\
\hline \multirow[t]{2}{*}{ I am able to understand most political issues easily. } & 69 & 120 & 49 & 47 & 23 & 2.67 & 1.329 \\
\hline & $(22.4)$ & $(39.0)$ & $(15.8)$ & $(15.3)$ & $(7.5)$ & & \\
\hline \multirow{2}{*}{ The government cares a lot about what all of us think about new laws. } & 29 & 52 & 75 & 99 & 53 & & \\
\hline & $(9.4)$ & $(16.9)$ & $(24.4)$ & $(32.1)$ & $(17.2)$ & 2.54 & 1.341 \\
\hline \multirow[t]{2}{*}{ The government is doing its best to find out what people want. } & 35 & 70 & 46 & 84 & 73 & & \\
\hline & $(11.4)$ & $(22.7)$ & $(14.9)$ & $(27.3)$ & $(23.7)$ & 3.46 & 1.381 \\
\hline \multirow[t]{2}{*}{ When people get together to demand change, the leaders in government listen. } & 38 & 53 & 42 & 113 & 62 & & \\
\hline & $(12.3)$ & $(17.2)$ & $(13.6)$ & $(36.7)$ & $(20.2)$ & 3.50 & 1.440 \\
\hline \multirow[t]{2}{*}{ I know more about politics than most people my age. } & 35 & 80 & 47 & 91 & 55 & & \\
\hline & (11.4) & $(26.0)$ & (15.3) & $(29.5)$ & (17.8) & 2.72 & 1.415 \\
\hline
\end{tabular}

Note: Strongly Agree: SA Agree: A Neutral: N Disagree: DA Strongly Disagree: SD

The mean understanding political issues of the respondent was 2.48 of issues with the standard deviation of 1.401 . When the researcher asked about the statements; government cares a lot about what all of us think for new laws, $17.2 \%$ respondents are strongly disagree and they think that government does not care about the public opinion whereas $24.4 \%$ respondents were neutral and had no opinion about the new laws and government responsiveness. One third $32.1 \%$ respondents were disagree with the statement that have do not think that government are making new laws for the welfare of the public. The mean understanding about new laws of the respondent was 3.46 of understanding with the standard deviation of 1.329. When the researcher asked about the statements the government is doing its best to find out what people want, $23.7 \%$ respondents were those who are strongly disagree with the gov- ernment performance whereas $14.9 \%$ respondents were among neutral and had no opinion about government grading. One fourth $27.3 \%$ respondents were disagree with the statement that the government is nothing doing anything for the public. The mean government performance of the respondent was 2.54 of better performance with the standard deviation of 1.341. When the researcher asked about the statements when people get together to demand change, the leaders in government listen, $20.2 \%$ of the respondents strongly disagree with the government performance that they listen about the demands of the public whereas 13.6\% of the respondents were neutral and had no opinion about government marking. One third $36.7 \%$ of the respondents were disagree with the statement that the government is not doing anything for the public and they did not accepted the general public demands for change. The mean people 
demand for change was 2.67 of demands with the standard deviation of 1.381.In response to the statement; I know more about politics than most people of my age, $17.8 \%$ of the respondents strongly disagreed that they do not know about the politics whereas $15.3 \%$ respondents were among those who were neutral and had no opinion about their understanding on politics. One fourth i.e., $29.5 \%$ of the respondents were disagree with the statement that they do not know more about the politics. The mean awareness about the politics was 2.72 with the standard deviation of 1.415 .

\section{CONCLUSION}

The present research was aimed to study the role of social networks in enhancing the youth political participation. It concluded that majority of the respondents were young having their educational status between intermediate to bachelor and actively running the political campaigns. Families of the respondents were supportive to their young children to play their role in the political and civic engagement. It was found that social networks have a strong influence on the propensity of youth to participate in politics. Specifically, it was found that social networks create opportunities for youth to gather information about politics that allows them to live beyond personal resource constraints. The study provided evidence that the effect of social networks on participation is contingent on the amount of political discussion that occurs in youth. The study also explains that social networks play a crucial role in explicating the role of other factors that predict participation, such as group membership and individual resource.

Huckfeldt (2001) concluded that the youth interests in the campaign is a statistically significant predictor of political participation in the social interaction, This is likely due to the fact that political discussion is related to a youth interest in political topics. This present research shows that political discussion is not purely driven by political interest but also by the motivations of the youth, perceived levels of political knowledge, and shared political activities through social networks.

A common explanation of group membership effects is that they provide individuals with opportunities to develop individual civic skills (Verba, Schlozman, \& Brady, 1995). It is concluded that if we want to improve our understanding of how people become politically active, we are to enhance our social networks.

\section{LIMITATIONS AND RECOMMENDATIONS}

Like any other research, this study has some limitations. Due to scarcity of time and resources, only students from universities in province of Punjab were selected. A more diverse respondent group would give more reliable findings and useful insights. Thus, it is recommended to scholars to keep on investigating this research domain so that more reliable findings can be obtained.

\section{REFERENCES}

Allen, J. C. (2018). Against all odds: Rural community in the information age. London, UK: Routledge.

Coleman, W. D. (1991). Fencing off: Central banks and networks in Canada and the United States. In Mayntz, R., and Marin, B. (Eds.)) policy networks: Empirical evidence and theoretical considerations, 209-234. New York, NY: Willey and John Son's.

European Union Election Observation Mission. (2013). The European union election observation mission to Pakistan 2013. Retrieved from https://urlzs.com/gUFx (accessed on 14 July, 2017)

Fukuyama, F. (1995). Trust: The social virtues and the creation of prosperity. New York, NY: Taylor and Francis.

Huckfeldt, R. (2001). The social communication of political expertise. American Journal of Political Science, 45(2), 425-438. doi:https://doi.org/10.2307/2669350

Mansouri, S., \& Mhunpiew, N. (2016). Leadership is skin deep: A new way of being through inside-out effect of leadership and its strategies in teaching. Journal of Advances in Humanities and Social Sciences, 2(3), 133-142. doi:https://doi.org/ 10.20474 /jahss-2.3.2

Norris, P. (2002). The bridging and bonding role of online communities. Harvard International Journal of Press/Politics, 7(3), 3-13. doi:https://doi.org/10.1177/1081180x0200700301

Nuchso, N., Tuntivivat, S., \& Klayklueng, P. (2016). The effect of learning organization and servant leadership on childcentered teaching behavior with the mediating role of knowledge sharing in education of Chanthaburi Diocese schools. International Journal of Humanities, Arts and Social Sciences, 2(5), 181-188. doi:https://doi.org/10.20469/ijhss.2 .20004-5

Putnam, R. D. (2001). Bowling alone: The collapse and revival of American community. New York, NY: Simon and Schuster. 
Ryan, V. D., Agnitsch, K. A., Zhao, L., \& Mullick, R. (2005). Making sense of voluntary participation: A theoretical synthesis. Rural Sociology, 70(3), 287-313. doi:https://doi.org/10.1526/0036011054831198

Schmitt, B., \& Lup, 0. (2013). Seeking the soul of democracy: A review of recent research into citizens' political talk culture. Swiss Political Science Review, 19(4), 513-538. doi:https://doi.org/10.1111/spsr.12051

Solihah, R., Djuyandi, Y., \& Rahmatunnisa, M. (2018). The influence of regional head candidates quality towards political participation of society in the local election. Journal of Advanced Research in Social Sciences and Humanities, 3(2), 52-58. doi:https://doi.org/10.26500/jarssh-03-2018-0202

Sproull, L., Conley, C. A., \& Moon, J. Y. (2005). Prosocial behavior on the net the social net: Understanding human behavior in cyberspace. Oxford, UK: Oxford University Press.

Stern, M. J., \& Adams, A. E. (2010). Do rural residents really use the internet to build social capital? An empirical investigation. American Behavioral Scientist, 53(9), 1389-1422. doi:https://doi.org/10.1177/0002764210361692

Verba, S., Schlozman, K. L., \& Brady, H. E. (1995). Voice and equality: Civic voluntarism in American politics. Harvard , UK: Harvard University Press.

Wellman, B., \& Frank, K. (2001). Network capital in a multi-level world: Getting support from personal communities. Social Capital: Theory and Research, 4(6), 233-273. doi:https://doi.org/10.4324/9781315129457-10

Zaidi, S. A. (2013). The old and the new in naya Pakistan. Economic and Political Weekly, 4, 34-37. 